\title{
Needs Assessment and Survival Pattern of Elderly People in Rural Bangladesh
}

\author{
Rehena Parvin $^{1}$, Mst. Tahmina Sultana ${ }^{1}$, Mahmudul Hasan ${ }^{1}$, and Md. Mokter Ali ${ }^{1}$ \\ ${ }^{1}$ Department of Sociology and Social Work, Gono Bishwabidyalay, Mirzanagar, Savar, Dhaka-1344, Bangladesh. \\ *Correspondence: rehenapeya@gmail.com (Rehena Parvin, Lecturer, Department of Sociology and Social Work, Gono \\ Bishwabidyalay, Mirzanagar, Savar, Dhaka-1344, Bangladesh).
}

\begin{abstract}
At present, aging is a buzzword that is recognized as a global issue. Bangladesh recently experiences a significant number of people who have faced many types of challenges due to its huge number of elderly people. It is the multidimensional process of physical, mental, and social change, both males \& females aged $60^{+}$years. Aging is now a global problem and an upcoming threat for developing countries like Bangladesh. Major social problems of elder people in a rural area are their adjustment in their surroundings, special needs, care giving and care receiving, neglect and harassment. This research aimed to know the needs assessment and survival pattern of elderly people in a rural area. The study has been conducted qualitative and quantitative in nature with a sample size of 120 . Necessary data were collected through structured interview schedules, observation, questionnaires, and case study techniques. The survey findings indicate that elderly people are lack access to educational facilities, agricultural resources, decision-making process, sufficient family income, basic health care and they have faced social and physical problems such as lack of social security, personal security, burden feeling, loneliness, special services, heart disease, diabetics, sleeping disturbances, urinary and stomach problem, eye, hearing, dental problem. The government should have a social welfare policy to give special health and medical services through separate wards and units for elderly people.
\end{abstract}

Keywords: Needs assessments, Survival pattern, Elderly people, Socio-economic condition, and Bangladesh.

\section{INTRODUCTION:}

A changing population structure is occurring all over the world with a great number of older people. Human being passes his life span through five stages such as infancy, childhood, adolescence, adulthood and old age. Old age is the most miserable situations in a natural process of life and nobody can avoid it. A declining trend in both fertility and mortality rates has increased average life expectancy. At present, the ageing people have been increasing as an alarming rate. In Bangladesh, $60+$ years or older people are now $6 \%$ and it will be turn over $9 \%$ by 2025 (Wikipedia). The older people are in worse condition due to changing pattern of social saturation, poor health care, and health seekUniversePG I www.universepg.com ing behavior, illiteracy and insufficient income in Bangladesh. Specially, the older people lead a miserable life in rural community with minimum satisfaction of fundamental needs and rights along with financial exploitations and familial negligence. This research is mainly attempt to explore the needs assessments and survival patterns regarding fundamental rights and satisfactions of elderly people in rural area. It explores the demographic and socio-economic status, their various problems (Physical and Psychosocial), the attitude of family members, services received from government organizations and nongovernment organizations. At present, Bangladesh Government has been passed a welfare Act named as 
the parents' care Act 2013. Under social safety net policy, the government approved the national policy on older people 2014 in Bangladesh to establish human rights and security for the senior citizens as a financial, psycho-physical support along with various prioritized services for senior citizen (Islam et al., 2021).

In this connection, the World Health Organization also emphasizes to improve the socio-emotional wellbeing of the elderly people with a view to ensure the standard quality of life. This paper is highlighted to assess the background profile, investigate the needs assessment and the problems of elderly people and its consequences in rural area of Bangladesh.

\section{Rational of the Study}

This study found that, elderly people in rural area are facing various types of problems like social, physical, mental, financials and neglect which are related with their social isolation, loneliness, illness, fear, stress and suicidal tendency. So that, we have selected these issues to give guide line and direction to solve their problems.

\section{Objectives of the Study}

The main objective of the study is to investigate the needs assessment and survival pattern of elderly people in rural Bangladesh. The specific objectives are:

1) To know about the demographic, socio-economic and family structure of the respondents.

2) Exploring the needs assessment, survival pattern and suggestions of the older people in rural area.

3) Investigate the problems facing in rural area and find out the causes.

\section{Literature Review}

A review of books and magazines consistent with various research related to rural elderly is presented.The United Nations, at first declared the International Day of Older Persons at first October in 1991. Identify 18 principles fall into 5 categories like - 1) Independence; 2) Participations; 3) Care; 4) Self-fulfillment; 5) Dignity. The United Nations General Assembly recommendation for action in following areas health and nutrition's, protections of elderly consumers, housing and environment, family, social welfare, income security, employment and education.
Raham A.S.M. Atikur (2013; 179) His written seniority magazine "The old situation in Bangladesh and our doing",

The work of the society and the state in the older welfare is emphasized on organizing media and educational programs initiatives in Bangladesh. With the help of the religious leaders aware about the old age of citizens, making then actives and jealous. Young stars have to take initiatives for aged people to make the part in all the stages of nations building and countries development. There also emphasized on the issues of freedom of the elders, self-interests, care, etc. While discussing knowledge about the elderly, but there did not mention any specific system solving problem.

Hossain, sheikh Abir (p 47-61) survival pattern of older people in Alia affected areas of Bangladesh; Bangladesh Association for the aged and Institute of Geriatric Medicine (BAAIGM)

Survival pattern of older people in Aila affected areas of geriatrics. At present in Bangladesh the amount of old aged peoples is increasing a lot of faster than before. More than 60 years' elderly people can't maintain their rules properly in social, economic and cultural matter. Especially in the absence of economic insecurity, social isolation, physical depletion, lack of institution facilities, traditional values and traditional issues moving for away. Hossain Sheikh Abir said that, if we could provide proper training and micro credits they can manage their own livelihood. Instead of depending on family, old people can easily manage their own livelihood by small business and animal husbandry.

Vuncha Uddin Mohammad Hafiz and Tutul, Farjana Naynin (2013.p 214-217) seniority magazine "vision disabled problem and chances; A quailtative analysis."

Important goods of this study is to gives knowledge about the health, economic and social problem that elderly people face due to obstruction. The problems faced by the visually impaired elderly are financial problems, mental problems, housing problems, health problems, communication problems and medical issues and solving the problems of the visually impaired. Various benefits providing like a medical, housing, increasing amount of disabled allowance and adult allowance and other basic facilities. For example, bus, 
launches, train has a reserved seat for the elder people. They also suggested that, generating old age homes in every district and making arrangements for a low amount of rent or free rental and increasing social awareness about obstacles of ageing. But this study did not mention anything about visually impaired elderly to provide education and employment status.

The livelihood pattern of older person in slum area; a study on Dhaka city; Mollah Mohammad Mainuddin; Bangladesh Journal of Geriatrics; (p 35-43)

Mollah Mohammad Main Uddin discussed about the livelihood pattern and problems of elderly people. In this research, he found out that problem of family income, current occupation, socio-economic problem, medical facilities and recreational topics. This study identifies that most of the slum populations are illiterate only have received some initial, education and poverty is the biggest problems to fulfill their needs. Here the elderly does small things to get rid of their economic bad situation. They are engaged in some activities. Such as selling newspaper, begging, rickshaw driving, collecting plastic bottles etc. Elder people also does nothing in slum areas and dependent on the family members and they suffer from dignity.

The problem of aged population structure in Bangladesh problem of the urban aged women in Bangladesh; a socio-demographic study in Dhaka city; Khanam Pro. Dr. Firoza (P 1-9).

Old aged women of cities are faced such as social, mental, physical, early marriage and educational problems. Among the old age women, divorced women have relatively more problems, statistics shows that among 300 women there are $64 \%$ married old women, $7.67 \%$ are divorced, $1.66 \%$ is helpless old women and $0.67 \%$ is unmarried old women.

\section{Operational Definition}

Elder people - In general, the Asia-Pacific region is 60 years old and over age they are elderly. Older people are defined according to some features such as losing sight, reducing physical energy, ill health, loss of memory, loss of authority and honor etc. This research, a man over 60 years of old has been being treated as age older people.

Needs Assessment - Systematic process of determining, addressing needs or "gaps" between present con- ditions and desired conditions or "wants" is called needs assessments.

Survival Pattern - Expression of social and cultural advancement to protect rights and navigate emotional pain that elder people manage to continue or exist in spite of difficult circumstances.

Rural - A rural is a geographical area which has land based unique economic, social and production system that is located outside from towns and cities.

Problem - Problem is regarded as unwelcome, harmful and risk matter or situation that people want to resolve.

\section{METHODOLOGY:}

We have selected 120 individuals as sample (60 male \& 60 female) from two villages named by Sharif bag from Dhamrai Upazila and Noyarhat from Savar Upazila of Dhaka district in Bangladesh. Among these 2 villages we have selected 120 older people through purposive sampling.

This research was conducted by both qualitative and Quantitative method as we can say that it was followed by a mixed method. A list of aged people was selected purposively to conduct the research. All the elderly people of Bangladesh both male and female are the population of the study. The study data has been collected from both primary and secondary sources through interview schedule, case study and observation, published and unpublished research report, journals, books as well as from record and documents of relevant agencies. To collect primary data a semi-structured interview schedule (close and open ended) has been prepared for data collection, which was pre-tested prior to the field work in order to improve its reliability. Data have been collected from selected older persons by direct face to face interview. More over observation technique are applied to collect data.

A checklist has been prepared to conduct the case studies. Two case studies were conducted by using in-depth interview technique. After collecting data, this study used SPSS software for statistical analysis. Then data were analyzed with different simple statistical techniques and results were drawn. 


\section{Data processing and data analysis}

Table 1: Age distribution of the respondents.

\begin{tabular}{|c|c|c|c|c|c|c|}
\hline \multirow{2}{*}{ Socio-Economic Characteristics } & Male-N = 60 & & Female-N = 60 & & Both No= 120 & \\
\cline { 2 - 7 } & Frequency & $\mathbf{\%}$ & Frequency (f) & $\mathbf{\%}$ & Frequency (f) & \% \\
\hline Age Composition & & & & & & \\
\hline $60-65$ year & $(17)$ & 28.33 & $(13)$ & 21.67 & $(30)$ & 25 \\
\hline $66-70$ year & $(12)$ & 20 & $(20)$ & 33.33 & $(32)$ & 26.67 \\
\hline $71-75$ year & $(14)$ & 23.34 & $(17)$ & 28.33 & $(31)$ & 25.83 \\
\hline $76+$ & $(17)$ & 28.33 & $(10)$ & 16.67 & $(27)$ & 22.5 \\
\hline Total & & $\mathbf{1 0 0}$ & & $\mathbf{1 0 0}$ & & $\mathbf{1 0 0}$ \\
\hline
\end{tabular}

The above Table 1 shows among the respondents, the people aged $60-65$ years is $25 \%$. Among them, the female is $21.67 \%$ and the male $28.30 \%$, the people aged $65-70$ years is $26.67 \%$. Among them female is $33.33 \%$ and male $20 \%, 71-75$ (Both male and female) aged $25.83 \%$ among them, the age of women is $28.33 \%$ and the male is $23.34 \%$. Study showed in Table 2, $80 \%$ of Islamist among the respondent. Among them, female respondents are $76.67 \%$ and male is $83.33 \%$. $23.33 \%$ female and $16.67 \%$ male respondents are flowing Traditional (Sonaton) religion. Other religions are not found. The result showed in Table 3 the majority of the older people were illiterate. Among them $66.66 \%$ male and $71.66 \%$ female and $81.67 \%$ (Both male and female) was Illiterate. $13.31 \%$ male and $11.66 \%$ female were literate. Among them $10 \%$ male and $15 \%$ female had completed primary education. Only $10 \%$ male and $1.66 \%$ female had completed secondary education. None of the respondents are highly educated. From the result in Table 4 it is seen that among the respondents, male $75 \%$ and female $56.67 \%$ both $65.83 \%$ are Married and 3.33\% male is unmarried/ single. $3.33 \%$ female were separated from their husband and 5\% female were divorced. $21.67 \%$ male Widow and $35 \%$ female were Widower who do not live together are mostly dependent on their children.

Table 2: Religion: Religious affiliation of the respondents.

\begin{tabular}{|c|c|c|c|c|c|c|}
\hline \multirow[t]{2}{*}{ Religion } & Male-N = 60 & & Female- $N=60$ & & Both No $=120$ & \\
\hline & Frequency & $\%$ & Frequency (f) & $\%$ & Frequency (f) & $\%$ \\
\hline Islam & $(50)$ & 83.33 & $(46)$ & 76.67 & $(96)$ & 80 \\
\hline Sonaton & (10) & 16.67 & (14) & 23.33 & (24) & 20 \\
\hline Total & & 100 & & 100 & & 100 \\
\hline
\end{tabular}

Table 3: Educational Qualification of the respondent.

\begin{tabular}{|c|c|c|c|c|c|c|}
\hline Educational Qualification & Male-N $=\mathbf{6 0}$ & & Female-N = 60 & & Both No= 120 & \\
\hline & Frequency & $\mathbf{\%}$ & Frequency (f) & $\mathbf{\%}$ & Frequency (f) & \% \\
\hline Illiterate & $(40)$ & 66.66 & $(43)$ & 71.66 & 98 & 81.67 \\
\hline Literate & $(8)$ & 13.33 & $(7)$ & 11.66 & & \\
\hline Primary & $(6)$ & 10 & $(9)$ & 15 & 15 & 12.5 \\
\hline Secondary & $(6)$ & 10 & $(1)$ & 1.66 & 7 & 5.83 \\
\hline Total & & $\mathbf{1 0 0}$ & & $\mathbf{1 0 0}$ & & $\mathbf{1 0 0}$ \\
\hline
\end{tabular}

Table 4: Marital Status - At present marital status of the respondents.

\begin{tabular}{|c|c|c|c|c|c|c|}
\hline Present marital status & Male-N = 60 & & Female-N = 60 & & Both No= 120 & \\
\cline { 2 - 7 } & Frequency & $\mathbf{\%}$ & Frequency (f) & $\mathbf{\%}$ & Frequency (f) & $\mathbf{\%}$ \\
\hline Married & $(45)$ & 75.00 & $(34)$ & 56.67 & $(79)$ & 65.83 \\
\hline Unmarried/Single & $(2)$ & 3.33 & & & $(2)$ & 1.67 \\
\hline Separated & & & $(2)$ & 3.33 & $(2)$ & 1.67 \\
\hline Divorce & & & $(3)$ & 5 & $(3)$ & 2.5 \\
\hline Widow/Widower & $(13)$ & 21.67 & $(21)$ & 35 & $(34)$ & 28.33 \\
\hline Total & & $\mathbf{1 0 0}$ & & $\mathbf{1 0 0}$ & & $\mathbf{1 0 0}$ \\
\hline
\end{tabular}




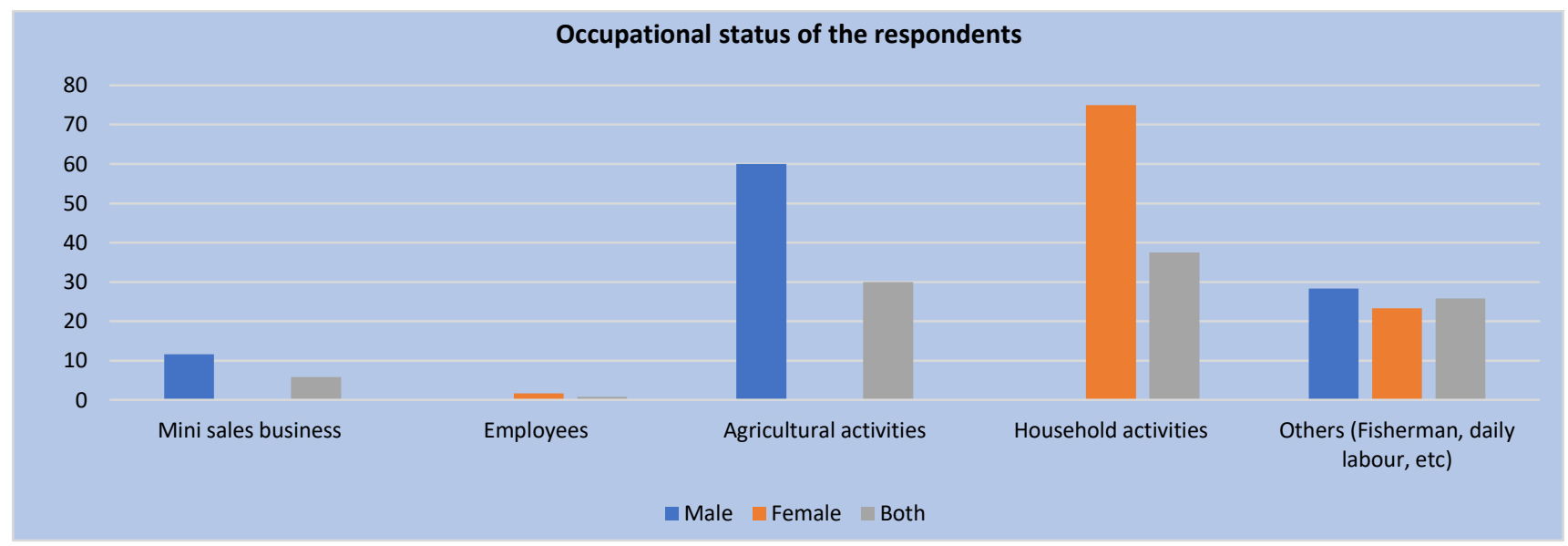

Fig 1: Occupational Status - At present occupational status of the respondents.

The Fig 1 shows that the respondents of the older people are poor and their economic facilities and job opportunities are limited. $11.67 \%$ male respondents are engaged with Mini sales business, employed female is $1.67 \%$, Agricultural $60 \%, 75 \%$ housewife are related with Household activities. Among all women respondents, no women respondents are businessmen. Male $28.33 \%$ and female $23.33 \%$ are related with others activities such as Fisherman, daily labor, baggers, boatman. From the current study in Table $\mathbf{5}$ it is revealed that $33.33 \%$ of the aged men and $33.34 \%$ of the aged women live in joint families, $53.33 \%$ male and 63.33 female respondents live in nuclear families and $13.34 \%$ male and $3.33 \%$ female live in alone. This implies that the family bondage in that society is more or less very strong and most of the respondents want to live in joint family to get companions.

Table 5: Family Structure of the respondents.

\begin{tabular}{|c|c|c|c|c|c|c|}
\hline \multirow{2}{*}{ Family Structure } & Male-N= 60 & & Female-N = 60 & & Both No= 120 & \\
\cline { 2 - 7 } & Frequency & $\mathbf{\%}$ & Frequency (f) & $\mathbf{\%}$ & Frequency (f) & \% \\
\hline Joint & $(20)$ & 33.33 & $(20)$ & 33.34 & 40 & 33.33 \\
\hline Nuclear & $(32)$ & 53.33 & $(38)$ & 63.33 & 70 & 58.33 \\
\hline Live alone & $(8)$ & 13.34 & $(2)$ & 3.33 & 10 & 8.34 \\
\hline Total & & $\mathbf{1 0 0}$ & & $\mathbf{1 0 0}$ & & $\mathbf{1 0 0}$ \\
\hline
\end{tabular}

Dulling place of the respondent

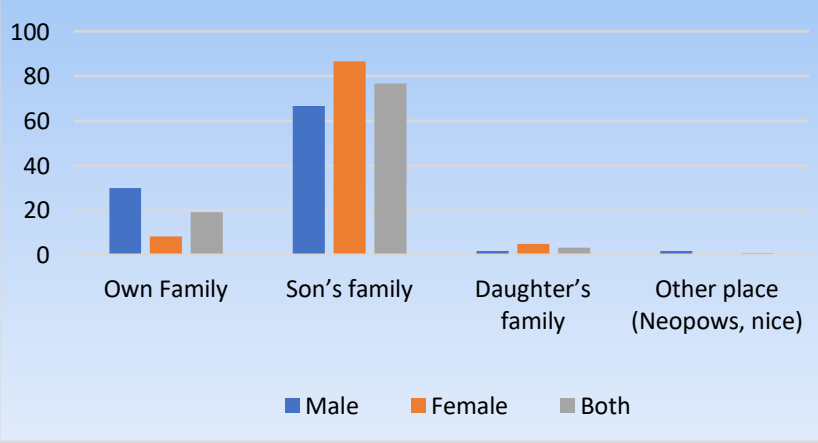

Fig 2: At present Dwelling place of the respondent.

From the Fig 2, it is observed that among the respondents, male $30 \%$ and female $8.33 \%$ live in own family, $66.66 \%$ male and $86.67 \%$ female live in son's family, $1.67 \%$ male and $5 \%$ female live in daughter's UniversePG I www.universepg.com family and $1.67 \%$ male live in nephew's family. At present dulling place of the respondents represent that most of the son have taken responsibility of their elder parents in our country. In this Table 6 it is showed that among the respondents, Male $(88.33 \%)$ and female (70\%) both $79.17 \%$ eat food three times a day. Male (11.67\%) and female (28.33\%). Both $20 \%$ eat food two times a day. It shows that most rural men and women eat three meals per day. Many people who ate two meals per day because of physical illness and economic problems are behind two meals per day. It is seen in this table, among respondent's male (11.67\%) and female $(28.33 \%)$, both $20 \%$ eat food at morning and noon. male $(88.33 \%)$ and female $(70 \%)$ both $79.17 \%$ eat at morning, noon and night among the respondents, only $0.83 \%$ of women eat breakfast at the morning, noon, evening and night. It shows that most 
respondents prefer to eat food at morning, noon and night. The Table 6 above shows that, among the respondents, male (11.67\%) and females $(1.67 \%)$ both $6.67 \%$ eat rice, fish, meat and vegetables. Male $(83.33 \%)$ and female $(70 \%)$ both $76.67 \%$ eat rice, pulses, fish and vegetables. Men (5\%) and female (28. $33 \%$ ) both $16.66 \%$ eat bread, rice, pulses, so it's seen that most of the female and male eat rice, pulses, fish and vegetables.

Table 6: How many times eat.

\begin{tabular}{|c|c|c|c|c|c|c|}
\hline \multirow{2}{*}{ Taken food } & Male- $N=60$ & & Female-N $=60$ & & Both No $=120$ & \\
\hline & Frequency (f) & $\%$ & Frequency (f) & $\%$ & Frequency (f) & $\%$ \\
\hline 2 times & $(7)$ & 11.67 & $(17)$ & 28.33 & 24 & 20 \\
\hline 3 times & (53) & 88.33 & $(42)$ & 70 & 95 & 79.17 \\
\hline 4 times & & & (1) & 1.67 & 1 & 0.83 \\
\hline Total & & 100 & & 100 & & 100 \\
\hline \multicolumn{7}{|l|}{ Times of eating } \\
\hline Morning to afternoon & $(7)$ & 11.67 & $(17)$ & 28.33 & 24 & 20 \\
\hline Morning, Afternoon, Night & $(53)$ & 88.33 & $(42)$ & 70 & 95 & 79.17 \\
\hline Morning, Afternoon, Evening, Night & & & $(1)$ & 1.67 & 1 & 0.83 \\
\hline Total & & 100 & & 100 & & 100 \\
\hline \multicolumn{7}{|l|}{ Kind of food } \\
\hline Rice, Fish, Meat, Vegetables & (7) & 11.67 & (1) & 1.67 & 8 & 6.67 \\
\hline Rice, Dal, Vegetable, Fish & $(50)$ & 83.33 & $(42)$ & 70 & 92 & 76.67 \\
\hline Bread, Rice, Dal & (3) & 5 & (17) & 28.33 & 20 & 16.66 \\
\hline Total & & 100 & & 100 & & 100 \\
\hline
\end{tabular}

Table 7: Present monthly income of the respondents.

\begin{tabular}{|c|c|c|c|c|c|c|c|c|c|}
\hline \multirow{2}{*}{\multicolumn{2}{|c|}{ At present income }} & \multicolumn{2}{|c|}{ Male-N = 60} & & Female-N $=60$ & & \multicolumn{2}{|l|}{ Both No $=120$} & \\
\hline & & \multicolumn{2}{|c|}{ Frequency } & $\%$ & Frequency (f) & $\%$ & \multicolumn{2}{|l|}{ Frequency (f) } & $\%$ \\
\hline \multicolumn{2}{|c|}{ Yes } & \multicolumn{2}{|c|}{ (31) } & 51.67 & $(8)$ & 13.33 & \multicolumn{2}{|l|}{39} & 32.5 \\
\hline \multicolumn{2}{|c|}{ No } & \multicolumn{2}{|c|}{ (29) } & 48.33 & $(52)$ & 86.67 & \multicolumn{2}{|l|}{81} & 67.5 \\
\hline \multicolumn{2}{|c|}{ Total } & & & 100 & & 100 & & & 100 \\
\hline \multicolumn{10}{|c|}{ If, yes, Nature of present income: } \\
\hline $2000-3000$ & $(2)$ & 3.34 & \multicolumn{2}{|l|}{ (1) } & 1.67 & \multicolumn{2}{|l|}{3} & \multicolumn{2}{|l|}{2.5} \\
\hline $4000-5000$ & (4) & 6.67 & \multicolumn{2}{|l|}{ (1) } & 1.67 & \multicolumn{2}{|l|}{5} & \multicolumn{2}{|l|}{4.17} \\
\hline $6000-7000$ & (9) & 15 & \multicolumn{2}{|l|}{ (2) } & 3.33 & \multicolumn{2}{|l|}{11} & \multicolumn{2}{|l|}{9.16} \\
\hline Others & (17) & 28.33 & \multicolumn{2}{|l|}{ (4) } & 6.67 & 21 & & \multicolumn{2}{|c|}{17.5} \\
\hline \multicolumn{10}{|c|}{ If, no, Nature of past income: } \\
\hline $3000-4000$ & (3) & 5 & \multicolumn{2}{|l|}{ (12) } & 20 & \multicolumn{2}{|l|}{15} & \multicolumn{2}{|l|}{12.5} \\
\hline $5000-6000$ & (14) & 23.34 & \multicolumn{2}{|l|}{$(28)$} & 46.67 & \multicolumn{2}{|l|}{42} & \multicolumn{2}{|l|}{35} \\
\hline $7000-8000$ & (10) & 16.67 & \multicolumn{2}{|l|}{ (9) } & 15 & \multicolumn{2}{|l|}{19} & \multicolumn{2}{|l|}{15.84} \\
\hline Others & (1) & 1.67 & (3) & & 5 & 4 & & 3.33 & \\
\hline Total & & 100 & & & 100 & & & 100 & \\
\hline
\end{tabular}

It is observed from the above Table 7 that $51.67 \%$ male and $13.33 \%$ female have involved with earning sources and other do not have any involvement with earning sources. Analyze the data, it is found that present earning of the respondents between tk. (20003000 ) earnings $2.5 \%$, (4000-5000) earns $4.17 \%$, (60007000 ) earns $9.16 \%$ more than (7000) $17.5 \%$.The previous income of those who currently do not earn (3000 - 4000) earning money 12.5\%, (5000-6000) earning UniversePG I www.universepg.com money 35\%, and (7000-8000) earning money $15.84 \%$, and earns over 8000 taka's was only $3.33 \%$ respondents. The Table 8 represents, among the respondents, male (51.67\%) and Female (33.33\%) Both $42.5 \%$ their income is enough to pay personal and family expenses. Male (48.33\%) and female (66.67\%) and both $57.5 \%$ their income is insufficient to carry both personal and family expenses. It is seen of this table, among the respondents who have no own ability 
to manage living cost, male $(26.66 \%)$ and female (46. $66 \%$ ) Both $36.67 \%$ the cost of living is done by the son. Male $(11.66 \%)$ and female $(10 \%)$ Both $10.84 \%$ daughter bear living cost. Only male (10\%) and $10 \%$ female respondents are managing the cost by the help of neighbors, grandchild, old age allowance by govt. and beggary. It shows that women are more dependent on others (Son- Daughter) compared to men.

Table 8: Whether your income is sufficient to cover your personal and familial expenses.

\begin{tabular}{|c|c|c|c|c|c|c|}
\hline \multirow[t]{2}{*}{ Sufficiency of income } & Male- $\mathrm{N}=\mathbf{6 0}$ & & Female-N = 60 & & Both No $=120$ & \\
\hline & Frequency & $\%$ & Frequency (f) & $\%$ & Frequency (f) & $\%$ \\
\hline Yes & $(31)$ & 51.67 & $(20)$ & 33.33 & 51 & 42.5 \\
\hline No & (29) & 48.33 & (40) & 66.67 & 69 & 57.5 \\
\hline Total & & 100 & & 100 & & 100 \\
\hline \multicolumn{7}{|c|}{ If no, How do you manage your present cost: } \\
\hline \multicolumn{7}{|l|}{ At present manage the cost } \\
\hline Son's help & 16 & 26.66 & (28) & 46.66 & 44 & 36.67 \\
\hline Daughter help & 7 & 11.66 & (6) & 10 & 13 & 10.84 \\
\hline $\begin{array}{c}\text { Others (neighbors, grandchild, old age } \\
\text { allowance by govt. beggary) }\end{array}$ & 6 & 10 & (6) & 10 & 12 & 10 \\
\hline
\end{tabular}

Table 9: Decision making process of the respondents.

\begin{tabular}{|c|c|c|c|c|c|c|}
\hline \multirow{2}{*}{ Decision Making } & Male-N $=60$ & & Female- $\mathrm{N}=60$ & & Both No $=120$ & \\
\hline & Frequency & $\%$ & Frequency (f) & $\%$ & Frequency (f) & $\%$ \\
\hline Yes & $(53)$ & 88.33 & $(40)$ & 66.67 & 93 & 77.5 \\
\hline No & (7) & 11.67 & 20 & 33.33 & 27 & 22.5 \\
\hline \multicolumn{7}{|c|}{ If yes what types of decision } \\
\hline Economical & (35) & 58.33 & $(23)$ & 38.34 & 58 & 48.33 \\
\hline Political & (5) & 8.33 & (2) & 3.33 & 7 & 5.83 \\
\hline Social & (13) & 21.67 & (15) & 25 & 28 & 23.34 \\
\hline \multicolumn{7}{|c|}{ If no, why } \\
\hline Neglect & (5) & 8.33 & 5 & 8.33 & 10 & 8.33 \\
\hline Physically problem & (1) & 1.67 & 12 & 20 & 13 & 10.84 \\
\hline Imbalance & (1) & 1.67 & (3) & 5 & 4 & 3.33 \\
\hline Total & & 100 & & 100 & & 100 \\
\hline
\end{tabular}

In the above Table 9 it is found that among the respondent's male $(88.33 \%)$ and female $(66.67 \%)$, both $77.5 \%$ take part in the decision-making process. On the other hand, male (11.67\%) and female (33.33\%), both $22.5 \%$ don't participate in the decisions making process. In this table analysis, it is found that among the respondents who can participated in the decisionmaking process, male (58.33\%) and Female (38.34\%), Both $48.33 \%$ have taken economical decisions, Male $(8.33 \%)$ and female (3.33\%), Both $5.83 \%$ have taken the political decisions, Male $(21.66 \%)$ and female
(25\%), Both of the $23.34 \%$ making decision on social issues. In this Table 9, it is found that among the respondents, male $(8.33 \%)$ and female $(8.33 \%)$, both $8.33 \%$ may not participate in the decision-making process due to negligence. Male (1.67\%) and female (20\%), both $10.84 \%$ cannot participate in decision process for physical reasons. Male $(1.67 \%)$ and female $(5 \%)$, both $3.33 \%$ cannot participate in decision due to imbalance. Here it's found more are not participated due to negligence.

Table 10: At present faced problems of respondents.

\begin{tabular}{|l|c|c|c|c|c|c|}
\hline \multirow{2}{*}{ Problems } & Male-N = 60 & & Female-N = 60 & & Both No = 120 \\
\hline & Frequency (f) & $\%$ & Frequency (f) & $\%$ & Frequency (f) & $\%$ \\
\hline Yes & $(60)$ & 100 & $(60)$ & 100 & 120 & 100 \\
\hline \multicolumn{7}{|c|}{} \\
\hline
\end{tabular}




\begin{tabular}{|c|c|c|c|c|c|c|}
\hline $\begin{array}{l}\text { Mental problem (Psychological, Mental stress, } \\
\text { frustration, memory loss, using slang language, } \\
\text { suicidal thought, fear) }\end{array}$ & (20) & 33.33 & $(11)$ & 18.33 & 31 & 25.83 \\
\hline $\begin{array}{l}\text { Social problem (Lack of social security, personal } \\
\text { security, personality problem, neglect, threats, fee- } \\
\text { ling burden, Lack of treatment, special services, } \\
\text { loneliness) }\end{array}$ & (5) & 8.34 & & & 5 & 4.17 \\
\hline $\begin{array}{l}\text { Economical problem (Poverty, not giving money } \\
\text { for buying daily necessities) }\end{array}$ & $(27)$ & 45 & $(42)$ & 70 & 69 & 57.5 \\
\hline $\begin{array}{l}\text { Physical problem (Heart disease, diabetics, sleep- } \\
\text { ing disturbances, week, mobility problem, uri- } \\
\text { nary and stomach problem, skin and hair dis- } \\
\text { eases, eye, hearing and dental problem, and pain } \\
\text { in body. }\end{array}$ & $(60)$ & 100 & $(60)$ & 100 & $(120)$ & 100 \\
\hline Recreational problem & $(30)$ & 50 & $(40)$ & 66.67 & 90 & 75 \\
\hline Dowling problem & $(15)$ & 25 & $(35)$ & 58.33 & 50 & 42.66 \\
\hline
\end{tabular}

The result showed that Table 10 all the elder people are suffering different types of problems. Among the respondents, about male $33.33 \%$, female $18.33 \%$, both $25.83 \%$ are suffering mental problem such as psychological, mental stress, and frustration, memory loss, using slang language, suicidal thought and fear. 8.34 elderly men are suffering specific social problem such as lack of social security, personal security, personality problem, neglect, threats, feeling burden, Lack of treatment, special services and loneliness, $45 \%$ male and $70 \%$ female and both $57.5 \%$ problems of poor economic conditions. All the respondents felt specific health problems like heart disease, diabetics, sleeping disturbances, week, mobility problem, urinary and stomach problem, skin and hair diseases, eye, hearing and dental problem, pain in body. 50\% male and $66.67 \%$ female have suffered recreational problem. $25 \%$ male, $58.33 \%$ female, both $42.66 \%$ are suffering doweling problem. The Fig 2 is showed that $38.35 \%$ male, $35 \%$ female, both $36.67 \%$ have taken treatment for health problems but $61.65 \%$ male and $65 \%$, both $63.63 \%$ have taken no treatment due to their economic problems. Among the respondents who have taken treatment, about $3.33 \%$ male and $8.33 \%$ female Gonoshasthya Kendro Hospital, $6.67 \%$ male and $5 \%$ female going to Islampur Hospital, $16.66 \%$ male and $8.33 \%$ female taken treatment from Dhamrai Hospital, 1.67\% female taken treatment from Momotaz Hospital, 1.67\% male and $3.33 \%$ female going to Savar hospital and $10 \%$ male, $8.33 \%$ female, both $9.16 \%$ have taken treatment from local market, quack doctors, Kabiraj, Fakir and Pir.
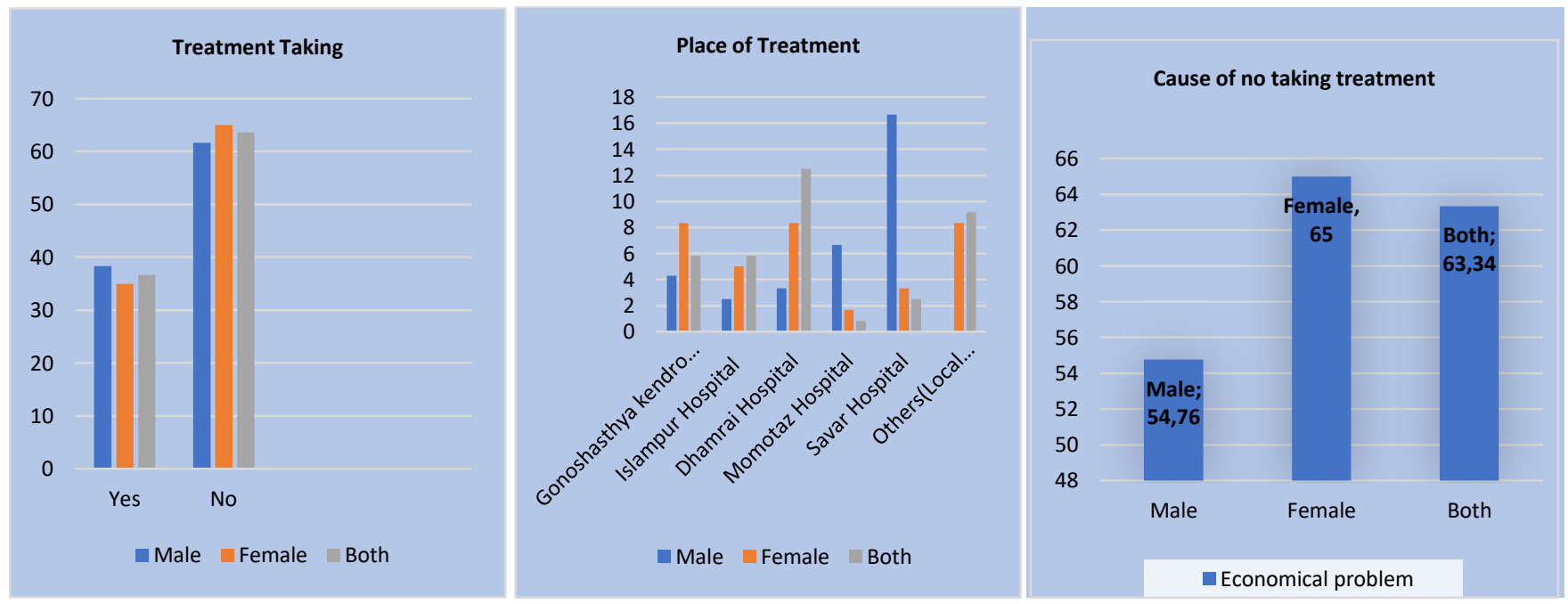

Fig 3: Treatment of the respondents. 


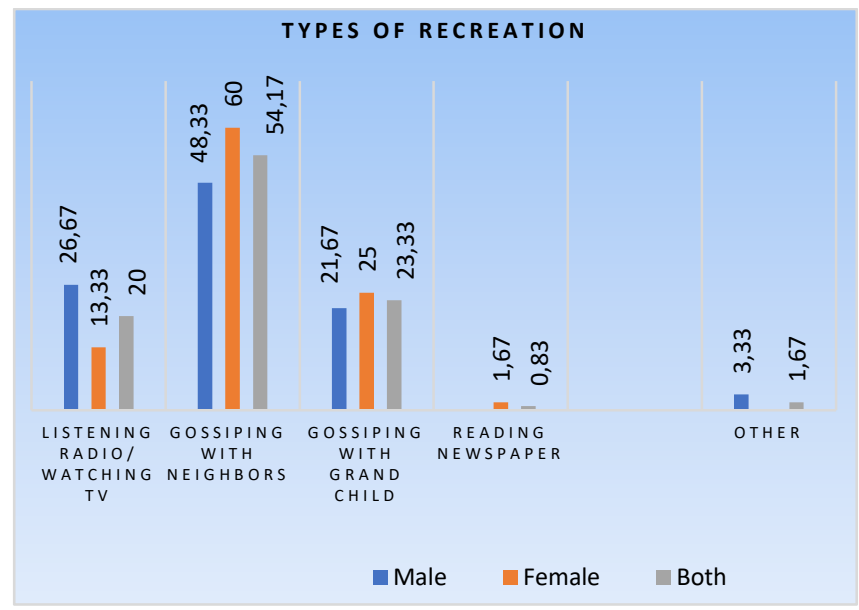

Fig 4: Leisure time of the respondents.

The Fig 4 shows that among the respondents, Male $(26.67 \%)$ and female $(13.33 \%)$, both $(20 \%)$ are listening radio and watching television. Male $48.33 \%$ and female $60 \%$ are gossiping with neighbors, male $21.67 \%$ and female $25 \%$ are gossiping with grandchildren, only $1.67 \%$ elderly female reading newspaper and $3.33 \%$ male are engaged with card carom playing to passing their leisure time. Large numbers of the respondents are passing their time gossiping with their neighbors. The above Table $\mathbf{1 0}$ shows that among the respondents, male (15\%) and female $(21.67 \%)$, both $18.33 \%$ felt loneliness and $85 \%$ male and $78.33 \%$ elder female never felt loneliness. Among the respondents who don't feel loneliness, male (61.67\%), female (63.33\%) and both (62.67\%) family gives companion, male (20\%) female (26.67\%) and both (23.33\%) spends leisure with grandchildren, male (13.33\%) female $(8.33 \%)$ and both (10.82) accompanied by children, male $(1.67 \%)$ female $(1.67 \%)$ both $(1.67 \%)$ accompanied by nephew and niece, only male $(3.33 \%)$ accompanied by others neighbor. In result we can see that, a majority of the males and females are accompanied by their family members.

Table 11: Feel loneliness.

\begin{tabular}{|c|c|c|c|c|c|c|}
\hline & Male-N = 60 & \multicolumn{2}{|c|}{ Female-N= 60 } & & Both No= 120 & \\
\cline { 2 - 7 } & Frequency (f) & \% & Frequency (f) & \% & Frequency (f) & \% \\
\hline Yes & $(9)$ & 15 & $(13)$ & 21.67 & 22 & 18.33 \\
\hline No & $(51)$ & 85 & $(47)$ & 78.33 & 98 & 81.67 \\
\hline \multicolumn{7}{|c|}{ If no, whom accompanied: } \\
\hline Children & $(8)$ & 13.33 & $(5)$ & 8.33 & 13 & 10.82 \\
\hline Nephew-Niece & $(1)$ & 1.67 & $(1)$ & 1.67 & 2 & 1.67 \\
\hline Grand child & $(12)$ & 20 & $(16)$ & 26.67 & 28 & 23.33 \\
\hline Family Members & $(37)$ & 61.67 & $(38)$ & 63.33 & 75 & 62.5 \\
\hline Others & $(2)$ & 3.33 & & & 2 & 1.67 \\
\hline Total & & 100 & & 100 & & 100 \\
\hline
\end{tabular}

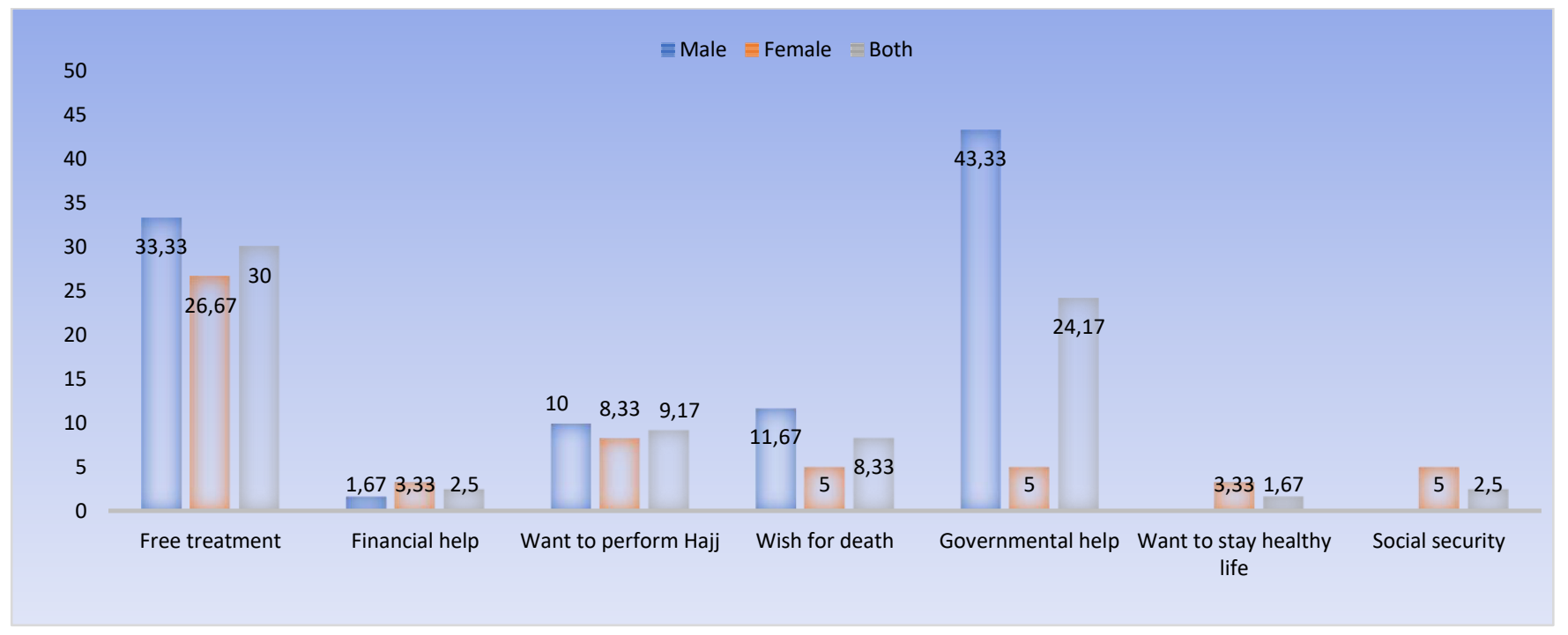

Fig 5: Demands and opportunities want to solve the problems of respondents. 
In the above Fig 5, we see that among the respondents, Male (33.33\%) and female (26.67\%), Both (30\%) opportunities for free treatment, Male $(1.67 \%)$ and female (3.33\%), Both (2.5\%) want to economic aid, Male $(10 \%)$ and female $(8.33 \%)$, Both $(9.17 \%)$ want to perform Hajj, Male (11.67\%) and female (5\%), both $8.33 \%$. Wish for death, Male $(43.33 \%)$ and female $(5 \%)$, both $24.17 \%$. Wishing for the governmental help, female $(3.33 \%)$. Wants to stay healthy life only female $(5 \%)$. Wants to visit relative's home. only female $(8.33 \%)$ seeks to social security.

\section{RESULT AND DISCUSSION:}

In view of this study, we see that maximum respondents are 66-70 years old, which is approximately $26.67 \%$. Besides, there are some older than over 70 years old. $80 \%$ respondents are believed in the religion of Islam and $20 \%$ are believed in the religion of Sanaton. The number of married females and male are 65 . $83 \%, 2.5 \%$ are divorced. After this, there are widows in the position, whose number is $28.33 \%$ and the separated women whose number is $1.67 \%$. Among the respondents, the illiteracy rate is higher, which is $81.67 \%$ and the primary pass is $12.57 \%$. Among the respondents most of the male elderly people work in agriculture, which is $30 \%$ and $37.5 \%$ female elderly people are engaged in household activities. Only .83\% is employed. Other activities that are in place after, for example, the unemployed, and the household work activities, that is, there is no income. There is no income of $67.5 \%$ and currently income is $32.5 \%$. Respondents, whose income is up to 7000taka they are fulfilling their personal and familial expenses by the help of their son's. Among the respondents, maximum elderly preferred to live joint family but $58.33 \%$ elderly people are living in nuclear family and $76.67 \%$ are lived with sons and $19.17 \%$ are lived in own family. $77.51 \%$ respondents are taking decision but $22.5 \%$ have no power to take decision due to neglect, physical problems and imbalance. The current problems faced by older people are physical problems which rate is $100 \%$, among the respondents $25.83 \%$. Having psychological problems and $75 \%$ have recreational problems. $36.67 \%$ respondents have taken treatments from governmental and private hospitals, local market, Kabiraj and Fakir and $63.63 \%$ are not taken any types of treatments due to financials problems.79.17\% rural elderly people have taken food in 3 times and $.83 \%$ have taken 4 times in a day. Maximum respondents are not maintained a balance diet and taken rice, dal, vegetable and fish in one item. A few numbers of respondents are taken meet in a week. Among the respondents $54.17 \%$ elderly are spending their time by gossiping with their neighbors and $23.33 \%$ are with their grandchild by telling story and playing, $20 \%$ listening radio and watching television and $1.6 \%$ playing card and cram in their leisure time. Only $18.33 \%$ fell loneliness and $81.67 \%$ elderly are accompanied by their children, nephew, niece, and grandchild and family members. The elders are looking forward to welfare of their life. $24.17 \%$ respondents are wanted to solve their problems by the glade of government, $9.17 \%$ wants to perform Hajj ,30\% wants to free treatments, $2.5 \%$ wants to visit relatives' home, $1.67 \%$ wants to stay healthy life, $8.33 \%$ wish to death and $8.33 \%$ wants to get social security.

\section{Case Study-01}

Rupchan Rajbongsi is a boatman. 70 years of old, he doesn't have enough strength to work, so he doesn't work. He spends his time sitting to home but he has two cow's milk is 1 or $2 \mathrm{~kg}$, and then he goes to sell it in the market. That is his amount of income. Once this hardworking Rupchan Rajbongsi supported his family which including four members by his boatman profession. In time, the son got married separately. His daughter also got married too. Rupchan Rajbongsi had a small amount of land. He sold land and sent his son abroad. After coming from abroad his son's married and separated himself from his payments. Their son doesn't look after them. Rupchan and his wife have spent hardship of life. He is suffering from various diseases. But he cannot take any treatment. He has not enough money for treatment. His physical problem is knee pain, not properly seen in the eye. Sometime his daughter helps with a little money for treatment. In this situation Rupchan thinks government should help in the treatment of vulnerable adult which is his wish also.

\section{Case Study-02}

Padma Banu (65 years old) is a mother of 3 sons' and one daughter. Her son's and daughter all are married. She is living in a joint family with her son's daughter in laws and grandchildren. Once she used to her house 
hold alone. Because of their many agricultural lands, they have lots household activities. But now after age, her position in the family has become very unnecessary. Her son's perform all duties to her just only as a responsibility. It has been 12 years her husband Abdul Hamid died. A few years ago she fell slippery from the high ground as a result, she got hurt in the waist, without taking doctor's advice her younger son gone her pain hillers on that moment she got relive but later the pain continued to grow at a level that grew half of its body paralyzed. Now she cannot move alone her need to help with her daughter in laws. It is not possible to do any work due to physical disability. Her life is passing bad situation. She now thinks that if she had a good quality treatment and good come in the past then this situation wouldn't have happened. Now she has only one wish that Allah should let her die soon.

\section{Recommendation}

Financial insufficiency is main problems of elder people in Bangladesh. The elder people have to suffer not only for their livelihood but also loneliness, frustration, familial and social deprivation which make elders life difficult. The recommendations of the present study, the results knowledge and experience acquired by the elders are highlighted below.

1) Financial security is an important matter for the elderly. Increasing the target of the old age allowance program and the government's health and social welfare ministry needs to allocate annual and five-year annual plans and national budget money.

2) To provide separate services and free medical care, low travelling cost for the elderly people.

3) Have to organize institutional recreation in the area to remove loneliness or solitude.

4) To ensure safety and security of the elders, need to take steps to keep running the joint family system in force.

5) Family members and educational institutions should have given the moral education to respect the elders.

6) Proper implementation of Parents Care Act2013 of Bangladesh.

\section{Limitations}

The respondents try to avoid submitting their answer due to the misconception; they thought they will be get UniversePG I www.universepg.com involved in any problem. Many respondents are given with a very thoughtful answer and it was a shrinking between them.

\section{CONCLUSION:}

The elder population of Bangladesh is a significant part of the total population. The rate and member of elders in this country is increasing gradually. In these villages, most of the elder people are living under the poverty line due to breakdown of rural joint family structure, changes in family customs, activities and family values for which reasons the elders are gradually going to isolated places. The elders are deprived of many basic needs and services including medical care. The study shows that poor elder people in rural areas faces different types of difficult circumstances to meet their basic needs. They are suffering from various types of physical, mental, social and cultural problems. The programs that are going on for welfare of the elders in our country are less than requirements. So the time has come for the elders to do something new. This is why; government and people of Bangladesh have come forward for welfare of the elders by declaring solidarity with international strategy. So that, elders can enjoy peace in life and necessary steps should have taken by adopting proper information.

\section{ACKNOWLEDGEMENT:}

We are acknowledged to the respondents of our study and also we are grateful to some of our students who helped to collect data. We are thankful to the University authority for permitting to conduct the research.

\section{CONFLICTS OF INTEREST:}

There are no potential conflicts of interest among the authors.

\section{REFERENCE:}

1) Bangladesh Bureau of statistics (BBS), (2006). Ministry of planning, the Government of the people Republic of Bangladesh. Daily Inquilab, October 2, 1997.

2) Farah Naz Rahman, Hafiz T. A. Khan, Md. Jahangir Hossain, Antony Obinna, (2021). Health and wellbeing indigenizes older adults living in the tea gardens $\mathrm{BD}, P L O S O N E$ 16(3): e0247957.

https://doi.org/10.1371/journal.pone.0247957 
3) Haque, Md. Towhidul (BAAGM), (2012). Bangladesh journal of Geriatric, 47.

4) Hossain, sheikh Abir, survival pattern of older people in Alia affected areas of Bangladesh; Bangladesh Association for the aged and Institute of Geriatric Medicine (BAAIGM).

5) Islam. Md. Rabiul, (2010). Rural older women in Bangladesh; A study Bangladesh journal of Geriatrics, 45.

https://web3.du.ac.bd/researchDetails/110

6) Islam SA, Shanjabin S, Zaman Z, and Nibir MMAM. (2021). Measuring motivating potential score of diversified academic staffs of the government primary schools in Bangladesh, Asian J. Soc. Sci. Leg. Stud., 3(5), 209-217. https://doi.org/10.34104/ajssls.021.02090217

7) Khanam. Prof. Dr. Firoza vice principle (Retd) Govt. (Sadat Korotia collage, Tangail). Problems of the urban Aged women in Bangladesh A socio-demographic study in Dhaka city, Financed by; Social Science Research Council (SSRC)
8) Mollah Mohammad Mainuddin, (2013). The livelihood pattern of older persons in slum area, Bangladesh Journal of Geriatrics, pp. 1-48.

9) Rashid, Muhammad, Mamunur, (2017). Social economic and health condition among the elderly poor diabetic patient; A study in Birdem Bangladesh Journal of geriatrics, 50(52). http://www.cordaid.org/en/countries/Bangladesh

10) The Daily Star, (2013). In the occasion of International Veterans Day 2013 the main article of published supplement.

11) Vuncha Uddin, Mohammad Hafiza, Tultul and Farjana Najnin, (2013). Bangladesh Journal of Geriatrics, October, vision disabled problems and chances; A qualitative analysis; Bangladesh Association for the aged and institute of Geriatric medicine (BAAIGM).

12) World Health Organization (WHO), (1997). Measuring quality of life the world Health Organization quality of life Instruments (WHOQOL).

https://apps.who.int/iris/handle/10665/63482

Citation: Parvin R, Sultana MT, Hasan M, and Mokter MA. (2021). Assessment and survival pattern of elderly people in rural Bangladesh, Asian J. Soc. Sci. Leg. Stud., 3(6), 218-229.

https://doi.org/10.34104/ajssls.021.02180229 @) 